NBER WORKING PAPER SERIES

\title{
THE EFFECTS OF EDUCATION ON MORTALITY: EVIDENCE USING COLLEGE EXPANSIONS
}

\author{
Jason Fletcher \\ Hamid Noghanibehambari \\ Working Paper 29423 \\ http://www.nber.org/papers/w29423 \\ NATIONAL BUREAU OF ECONOMIC RESEARCH \\ 1050 Massachusetts Avenue \\ Cambridge, MA 02138 \\ October 2021
}

The authors claim no conflict of interest. We thank Enrico Moretti for generously providing the data on college openings. We also thank Joshua Goldstein, Adriana Lleras-Muney, participants of Health-Aging-Place working group at the University of Wisconsin-Madison, CenSoc Working Group at the University of Califorina-Berkeley, and seminar participants of the Data-Intensive Research Conference for their comments and suggestions. The authors would like to acknowledge financial support from NIA grant R01AG060109 and the Center for Demography of Health and Aging (CDHA) at the University of Wisconsin-Madison under NIA core grant P30 AG17266. The views expressed herein are those of the authors and do not necessarily reflect the views of the National Bureau of Economic Research.

NBER working papers are circulated for discussion and comment purposes. They have not been peer-reviewed or been subject to the review by the NBER Board of Directors that accompanies official NBER publications.

(C) 2021 by Jason Fletcher and Hamid Noghanibehambari. All rights reserved. Short sections of text, not to exceed two paragraphs, may be quoted without explicit permission provided that full credit, including $\odot$ notice, is given to the source. 
The Effects of Education on Mortality: Evidence Using College Expansions

Jason Fletcher and Hamid Noghanibehambari

NBER Working Paper No. 29423

October 2021

JEL No. I1,I23,I26

\begin{abstract}
$\underline{\text { ABSTRACT }}$
This paper explores the long-run health benefits of education for longevity. Using mortality data from the Social Security Administration (1988-2005) linked to geographic locations in the 1940census data, we exploit changes in college availability across cohorts in local areas. We estimate an intent to treat effect of exposure to an additional 4-year college around age 17 of increasing longevity by 0.13 months; treatment on the treated calculations suggest increases in longevity between 1-1.6 years. Some further analyses suggest the results are not driven by pre-tends, endogenous migration, and other time-varying local confounders. This paper adds to the literature on the health and social benefits of education.
\end{abstract}

\author{
Jason Fletcher \\ University of Wisconsin-Madison \\ La Follette School of Public Affairs \\ 1225 Observatory Drive \\ Madison, WI 53706 \\ and NBER \\ jfletcher@lafollette.wisc.edu \\ Hamid Noghanibehambari \\ University of Wisconsin-Madison \\ 1180 Observatory Drive \\ Unit 4401 \\ Madison, WI 53706 \\ noghanibeham@wisc.edu
}

A data appendix is available at http://www.nber.org/data-appendix/w29423 


\section{Introduction}

It is well documented that the returns to education go beyond labor market outcomes. Education not only has spillover effects for peers, colleagues, and other family members (Fruehwirth, 2014; Jaffe et al., 2006; Martins and Jin, 2008) but also shapes long-run outcomes such as health at older ages (Albouy and Lequien, 2009; Mazzonna, 2014) ${ }^{4}$. A recent review by Galama et al. (2018) classified the literature that establishes a causal path between education and health, health behavior, and mortality into three general categories: 1) studies that employ randomized controlled trials such as the Perry Preschool Program and Abecedarian which primarily provides early childhood education intervention (Campbell et al., 2014; Conti et al., 2016; Heckman et al., 2013); 2) within-twin variation in years of schooling as the primary education shock (Behrman et al., 2011; Lundborg et al., 2016; Madsen et al., 2010); 3) quasiexperimental settings with primary focus on school reforms which increase minimum school leaving age and compulsory schooling (Black et al., 2015; Clark \& Royer, 2013; Fischer et al., 2013; Fletcher, 2015; Gathmann et al., 2015; Kippersluis et al., 2011; Lager \& Torssander, 2012; Lleras-Muney, 2005; Mazumder, 2008; Meghir et al., 2018).

With the exception of twin/sibling studies, the literature concentrates on interventions and improvements at early ages or during K-12 education focusing on years of schooling as the primary explanatory variable and has offered mixed evidence. Some studies point to large positive effects for life expectancy and gains in mortality while other studies do not find any suggestive evidence and in some cases even opposite-signed coefficients (Albouy \& Lequien, 2009; Behrman et al., 2011; Buckles et al., 2016; Campbell et al., 2014; Conti et al., 2016; Gathmann et al., 2015;

\footnotetext{
${ }^{4}$ Many earlier studies within this literature examined cross-sectional associations of education and mortality without fully addressing the common endowments' influence in driving both education and health (Kravdal, 2008; Meara et al., 2017; Ross et al., 2012; Zajacova, 2006).
} 
Lundborg et al., 2016; Madsen et al., 2010; Meghir et al., 2018). This paper aims to extend this literature and provide new insight into the long-term effects of education by quantifying the benefits of higher education on old-age mortality.

We investigate whether changes in the number of available colleges in the local area when individuals are 17 years old could influence their age at death. We find robust evidence that the availability of 4-year colleges at the age of high school completion can influence their age at death. The reduced form effects are economically meaningful. For example, our most parametrized specification suggests that an additional college opening in own or neighboring counties raises the age of death by 0.13 months. This is equivalent to roughly 5 percent of white-nonwhite differences in old age mortality. Because college openings have modest direct effects on educational attainments, the treatment on the treated calculations suggest large effects, between 1-1.6 years of added life for older age individuals.

We implement a wide range of robustness exercises to control for family unobserved heterogeneity, assess for alternative standard error adjustments, consider alternative specifications, functional forms, and various measures of college access. In addition, we explore the possibility of endogeneity of college access, as people with specific demographic characteristics may migrate to areas that have experienced college expansions. In addition, we consider placebo tests that assign college expansions to the year individuals turn age 25,30 , and 35 , well after the age that college availability could have an effect on individual's education attainment.

Not surprisingly, the effects of college opening on old age death are heterogeneous. Additional heterogeneity analyses imply that the effects are more pronounced for males, blacks, individuals with higher parental education, lower county population, and those residing in the Midwest. Our paper contributes to the literature on the social and health benefits of education in 
two ways. First, this is the first study to link the construction of new colleges on education and later-life mortality. Second, while similar papers have used longitudinal data with limited observations, our new longitudinal dataset provides millions of observations which significantly adds power to our statistical tests. In addition, the increased sample size enables a wide range of heterogeneity analysis by cohort, place, and demographic.

The rest of the paper is organized as follows. Section 2 gives a review of related literature. Section 3 introduces the data sources and sample construction. In section 4, we discuss the econometric method and potential endogeneity concerns. Section 5 offers the main results and discusses additional analysis. Concluding remarks are provided section 6.

\section{Literature Review}

Education has spillover effects across a wide range of outcomes which can operate as a set of channels for health at older age, including age-at-death (Oreopoulos \& Salvanes, 2011). While there is a relatively large literature on education and mortality, most studies focus on years of education in general and exploit compulsory schooling laws or similar reforms as the shock to education and find mixed evidence (Albouy and Lequien, 2009; Buckles et al., 2016; Conti et al., 2010; Everett et al., 2013; Jemal et al., 2008; Kalediene and Petrauskiene, 2005; Kippersluis et al., 2011; Kravdal, 2008; Lager and Torssander, 2012; Lynch, 2003; Meara et al., 2017; Ross et al., 2012; Zajacova, 2006). In her seminal study, Lleras-Muney (2005) takes advantage of changes in compulsory schooling (child labor and compulsory attendance laws) as the instrument for education and builds a synthetic cohort from decennial censuses to measure 10-year mortality rates. She finds that an additional year of education leads to a 6.3 percentage point reduction in 10-year death rates. Mazumder (2008b) shows that these findings are not robust to adding state

trends. Black et al. (2015b) use Vital Statistics death records to investigate the effects of 
compulsory schooling laws on mortality and find that the gains in mortality can be explained by cohort and state fixed effects. Fletcher (2015) employs survey data (AARP Diet and Health Study) and instruments education with compulsory schooling laws and finds positive health effects and large gains in mortality. His calculations provide similar effects to the findings of Lleras-Muney (2005) but they are statistically insignificant.

Lleras-Muney et al. (2020) examines the association between education and old age longevity for cohorts born between 1906-1915 in the US. They link social security death records with 1940 full-count census and find that an additional year of education is associated with 0.4 higher age at death. In a similar study, Halpern-Manners et al. (2020) apply linking techniques to merge 1920 and 1940 full-count census covering males born between 1910-1920 with social security administrative mortality data and implement a twin-fixed-effect strategy to study the effect of education on mortality. They find that an additional year of schooling raises age at death by 0.3 years. These effects are slightly smaller than OLS estimates which suggests that common endowments such as genetic factors only modestly influence the education-mortality association in their sample.

Clark and Royer (2013b) apply a regression discontinuity design strategy to take advantage of schooling reforms in the UK and find that the reforms were successful in raising educational attainments and wages while they had no discernible effect on health and mortality. In a similar study, Meghir et al. (2018a) use the phase-in of a series of compulsory schooling reforms across different municipalities in Sweden as an educational promotion policy and find that although the reforms improved educational outcomes they did not have any statistical effect on mortality, health care utilization, and hospitalization. Using two French compulsory schooling reforms that increased school leaving age to 14 and 16, Albouy and Lequien (2009) find small and statistically 
insignificant evidence that education lowers mortality rates of affected cohorts. In contrast to these findings, Gathmann et al. (2015) exploit the compulsory schooling reforms across 15 European countries and find small but statistically significant effects of education on mortality among men with no impact on female mortality rates. Kippersluis et al. (2011) exploit a compulsory schooling reform in Netherland which significantly increased schooling to assess its impact on longevity. They find that an additional year of education reduces the likelihood of death before age 89 by 6 percent relative to the mean, conditional on survival up to age 81 .

A small literature has used quasi-experimental and sibling methods to examine the effects of college on older age health. Buckles et al. (2016) employ the deferment of the Vietnam war draft for college students as the source of identification to explore the effect of college education on cumulative mortality. They find that a 1 percentage point increase in college completion rate among men reduces their mortality rate by 0.95 fewer death per 1,000 . Their results suggest that raises in income and health insurance are plausible mechanisms of impact. Fletcher \& Frisvold, 2011 (2014) compare siblings in the Wisconsin Longitudinal Study to show college attendance is related to old age preventive care decisions and college quality is related to better weight outcomes in old age, respectively. ${ }^{5}$ Bautista et al. (2020) use the discontinuity in college attendance as a result of the 1973 military coup in Chile, which significantly reduced access to college for those reaching college age, and show that the reduction in access and enrollment was associated with higher age-adjusted mortality later in life.

\footnotetext{
${ }^{5}$ Fletcher \& Frisvold ( 2011)compare siblings in Add Health to show that college selectivity is associated with lower likelihood of tobacco and marijuana use in young adulthood.
} 


\section{Data Source}

The primary source of data comes from the Censoc project outlined in Goldstein et al. (2021). ${ }^{6}$ It uses death records from social security administration for individuals who die in old age and implement data-linkage techniques to link with full-count 1940 census records. We use the Censoc-Numident (hereafter Numident) dataset from this project which has linked 7.9 million individuals to the 1940 census who died between the years 1988-2005. We merge this data with the 1940 census extracted from Ruggles et al. (2020). There are three primary advantages of this linkage that help our identification strategy. First, the resulting sample size consists of millions of individuals, which is considerably larger than available longitudinal datasets and enables much more powerful statistical tests. Second, the county identifier in the 1940 census provides detailed granularity that can be used to match with the county-level college dataset, unlike state-of-birth indicators available in the Health and Retirement Study, Decennial Census, or American Community Survey data, among others. Third, we can observe other family member's socioeconomic characteristics such as parental education that we exploit in our robustness and heterogeneity analyses.

The data on county-level college counts are obtained from Currie and Moretti (2003b). It reports the total number (as well as some disaggregated categories) of 4-year and 2-year colleges at each county from 1940-onward. Figure 1 shows the geographic distribution of college inventory at 1940 (top panel) and changes in college counts (bottom panel). About 45 and 33 states had at least one county with a 4-year and 2-year college opening in our sample. ${ }^{7}$ About 80 percent of

\footnotetext{
${ }^{6}$ The name is extracted from the beginnings of census and social security administration.

${ }^{7}$ The states with no 4-year college expansions include: Delaware, DC, Montana, Utah, Wisconsin, and Wyoming. The states with no 2-year college expansions include: Alaska, Arizona, Arkansas, Delaware, DC, Idaho, Iowa, Montana, Nebraska, Nevada, New Jersey, Rode Island, South Dakota, Tennessee, Vermont, Virginia, West Virginia, and Wisconsin.
} 
counties experienced only one expansion. The counties with the higher number of openings include Los Angeles, CA with five new 4-year colleges and six new 2-year colleges, Nassau, NY with four new 4-year colleges, and Allegheny, PA with four new 2-year colleges. We merge this with our Numident dataset based on the county of residence and the year individuals turn age 17. This leaves us with 3,849,792 observations from cohorts who were born between the years 19231940 and died at ages 47-82 between the years 1988-2005.

Summary statistics of the final sample are reported in Table 1. To have a better picture of the demographic composition of this sample, we compare with that of the full-count 1940 census. The sample underrepresents females ( 0.43 vs 0.49$)$, underrepresents first-generation immigrants ( 0.3 vs 8.9 ), and overrepresents second-generation immigrants ( 0.14 vs 0.09$)$ while the share of whites, blacks, and Hispanics are quite similar to the 1940 census. The average age-at-death is 68.8 years or equivalently 831.4 months. Since the months of longevity provides a more accurate measure, we use age-at-death in months as the primary outcome. Figure 2 shows the geographic distribution of age-at-death by county of residence in 1940 .

\section{Econometric framework}

The identification strategy compares the age of death of individuals who, at the age of 17 , resided in counties that experienced a college expansion to those who resided in counties with no college openings, after a college opening compared to before the expansion. We operationalize this difference-in-difference model using the following regression:

$$
D A_{i c b}=\alpha_{0}+\alpha_{1} \operatorname{Coll}_{c, b+17}^{4 \text { year }}+\alpha_{2} \operatorname{Coll}_{c, b+17}^{2 \text { year }}+\alpha_{3} X_{i}+\zeta_{c}+\gamma_{b}+\varepsilon_{i c b}
$$

Where the outcome $(D A)$ is the death age of individual $i$ from birth cohort $b$ who, at the age of 17 , resided in county $c$. Since college openings could have spillover effects for college 
attendance decision of not only the residents of the county but also the residents of neighboring counties, we also create a second measure that aggregates our measure of college expansion to the college counts of own and neighboring counties, conditional on being in the same state. Therefore, the parameter Coll represents the total number of 4-year and 2-year colleges at the own and withinstate neighboring counties where the individual resided at age $17(b+17) .{ }^{8}$ In matrix $X$, we include some individual covariates including indicators for race/ethnicity, gender, first-generation immigrant, and second-generation immigrant. The county fixed effects and birth cohort fixed effects are represented by parameters $\zeta$ and $\gamma$, respectively. $\varepsilon$ is a disturbance term. In some additional specifications, we also include a county-by-year linear trend. We cluster the standard errors at the county level.

\subsection{Concerns over Endogeneity}

The parallel trend assumption behind the identification strategy -that the outcomes of those residing in the vicinity of a college opening would have followed the same path and been influenced by the same factors as the outcomes of those not exposed to a new college openingmay be violated for three primary reasons. First, changes in the number of colleges in an area could be correlated with changes in local and state-level regulations and legislations that impact, through education or other channels, the longevity of individuals. Moreover, college expansion could reflect other contemporaneous changes in the local economic and non-economic environment that, in turn, has long-term effects for residents. For example, city expansions could lead to additional college openings as well as improving health care access and better job opportunities, with plausibly positive long-term effects, or degrading environmental quality by raising pollution, with

\footnotetext{
${ }^{8}$ Appendix A shows that the results are quite robust and similar when we replace our measure of county by own county number of colleges or with own county and all neighboring counties regardless of the fact that they are within the same state or not.
} 
potentially negative cumulative effects for longevity. These omitted variables result in upwardbiased and downward-biased OLS coefficients for the former case and latter case, respectively. Even if we had a series of county-level covariates over the period of this study (1940-1957), these measures may not fully capture all relevant factors. We address this potential issue by adding mother (and father) fixed effects in our robustness examination. In particular, we compare the outcomes of siblings who share the same mother (father) and were exposed to a different number of colleges when aged 17 .

Second, the results could be driven by pre-trend changes in health levels that are revealed in age-at-death and cannot be absorbed by birth cohort and county fixed effects. To examine this pre-trend problem, we implement an event study analysis in which the event time is the opening of a new college. This strategy compares the outcomes of individuals aged 17 in different years relative to a college opening in their own and neighboring counties, conditional on fixed effects and covariates. The results, shown in two panels of Figure 4 for 4-year and 2-year colleges, do not consistent with important pre-trends. Compared to unexposed cohorts in counties with no expansion (event time=zero), cohorts who turn age 18 -above at the time of college opening (both panels) reveal no differences in their age-at-death. The event-time coefficients are small in magnitude and not statistically different from zero. For 4-year colleges, the coefficients of exposed cohorts start to rise in magnitude and become statistically significant for cohorts who turn age 16below at the time of college expansion. The overall difference-in-difference estimate that compares post-treatment to pre-treatment cohorts is $0.7(\mathrm{se}=0.15)$. However, we observe no post-treatment difference in the case of exposure to 2-year colleges. Important to our empirical strategy is the fact that we do not detect any pre-trend in outcomes for unaffected cohorts for both sets of college expansions. 
Third, people may migrate to a county that had a college opening either for attending college or for other reasons such as improved economic conditions, which resulted in college expansion in the first place. If individuals who chose to migrate have characteristics that are correlated with their health in the long run, the OLS results of equation 1 are biased as a result of this self-selection. For example, if whites migrate more than other races, because of their ability and affordability to move or their willingness to be more educated, there will be a sample selection problem and the results overestimate the true effects as whites have higher longevity and better health endowment for other reasons that cannot be fully captured by race dummies. To explore this potential source of endogeneity, we use a series of observable characteristics as the outcome of equation 1 . The results are reported in Table 2 for a specification with county and birth cohort fixed effects (panel A) as well as a specification that includes a county-specific trend in birth cohort (panel B). The results offer a mixed and inconsistent pattern of migration. Panel A suggests some association between 2-year college expansion and increases in the share of whites and Hispanics while the coefficients become negative and insignificant in panel $\mathrm{B}$. There is also an increase in individuals with higher parental education (columns 5 and 6 of panel A) as a response to an increase in 4-year colleges. Since education is a leading factor in family socioeconomic status, the reduction in the family's Duncan Socioeconomic Index (column 7, panel A) reveals an inconsistency. However, all the effects become small in magnitude and statistically insignificant when we add county trends.

As an additional step we implement a series of placebo tests by assigning the number of colleges to individuals at ages later than 17 , specifically, ages 25,30 , and 35 . If healthier individuals, who would have otherwise higher longevity, move to counties with college expansions for reasons related to overall trends of the county (e.g. better job opportunities) when they age 25, 
then the college availability in the new environment should be strongly associated with their health outcomes later in life. The results (shown in Table 3) do not provide evidence for this issue. The effects are quite small (relative to the main results) and in most cases statistically insignificant. Interestingly, the signs are reversed in specifications that include a county-specific trend for assignment at ages 25 (column 3) and 30 (column 6).

One may also argue that the window of observation in social security administration death record is narrow and does not include those who die earlier or later. Looking at the Vital Statistics cause-specific death record data from 1959-2017, roughly 39 percent of deaths to birth cohorts of 1923-1940 occur between 1988-2005 (Numident window). Comparing to deaths outside of this window (1959-1987, 2006-2017), Numident records are 1.3 percentage points less likely to be white, 4.6 percentage points less likely to be female, and 3.4 percentage points more likely to be black. We will show that, in our sample, the effects are stronger for 4-year colleges and that the effects are not statistically different among different races and ethnicity but more pronounced among males. Therefore, one possible concern in extending the results in this paper to the whole population is the overrepresentation of males for which the effects are stronger.

In another attempt to explore possible issues with the window selection of Numident, we replicate the main results using Censoc-DMF data which links death records of males who die between 1975 to 2005 with the 1940 census. This allows us to explore the effects of deaths that occurred up to 12 years before the start of Numident data. We apply the same sample selections and implement the same econometric method as in the main analysis in the text. These results are reported in Appendix B. The effects of the death window of 1988-2005 (similar to Numident) are virtually the same as the main results of section 5.1. However, the effects are small and even change the sign for the death window of 1975-1987. This may suggest that the effects on death 
age are also dependent on the selection of windows and that the effects of education on mortality are better detected at older ages.

\section{Results}

\subsection{Main Results}

Figure 3 shows the density distribution of age-at-death for counties with no colleges (never treated, top panel) and counties with at least one college opening (treated, bottom panel). Cohorts exposed to college expansions have 3.6 months higher age-at-death. To account for confounding factors, we turn our focus from this visual difference to the difference-in-difference strategy of equation 1. The main results are reported in Table 4 for specifications that include county and birth year fixed effects (column 1), individual covariates (column 2), and county-specific linear trend in birth cohort (column 3). The marginal effects of 4-year colleges are positive and very similar in columns 1 and 2 and drops by 35 percent when we add county-trends. It implies that a onestandard-deviation change in the number of 4-year colleges (14.8) is associated with roughly 2 months higher age-at-death, a 0.2 percent rise from the mean. While this result is a small effect, we can put it into perspective by comparing it with the marginal effects of other covariates, specifically, females, blacks, and other races. This effect is equivalent to 74 percent of the difference in age-at-death between people of other races and whites, 52 percent difference in blackwhite gap in age-at-death, and 29 percent of the difference in age-at-death of females versus males. Over the sample period, there are 729 counties with no 4-year colleges. Adding one 4-year college to these counties (an increase of 3.3 colleges) would increase the age-at-death of the population by 0.4 months, which closes the life expectancy gap between the US and other OECD countries by 2.4 percent. $^{9}$ The effect of 2 -year college expansion is mixed, negative for columns $1-2$ and

\footnotetext{
${ }^{9}$ Based on OECD health status reports, life expectancy of USA in 2008 was 77.9 and the average OECD countries was 79.3 .
} 
positive for column 3. However, they are small compared to 4-year college marginal effects and also statistically insignificant. To have a better comparison of the effects of 4-year versus 2-year colleges, we report the elasticities at the end of each column. The elasticity comparison reveals that the effect of the same changes in 4-year college expansion is much larger than 2-year college expansion, by a factor of 26 (column 2) to 9 (column 3).

The results reported here are intention-to-treat effects as the college expansion leads to college education of only a fraction of the population. Although we explore the direct link between college expansion and college education in section 5.3 and try to convert the marginal effects into treatment-on-treated effects in section 5.4, we should note that these effects provide a minimum benefit of college openings on long-run mortality outcomes.

Moreover, not all the positive effects of college opening operate through increases in own education. ${ }^{10}$ For instance, it could improve the education of the spouse which results in gains in mortality for both husband and wife (Jaffe et al., 2006; Spoerri et al., 2014). Therefore, college openings could affect mortality by increases in the education of other current and future family members rather than one's own education. Another aspect is the improvements in education of coworkers which in turn has possible health spillover for own mortality outcomes later in life (Martins and Jin, 2008).

\subsection{Robustness Checks}

In Table 5, we execute a wide range of robustness checks. One important concern is the omission of family background and, specifically, parental characteristics. However, the results are quite robust when we add mother-father schooling and family's socioeconomic index (column 2),

\footnotetext{
${ }^{10}$ This is the primary reason that we prefer a reduced-form analysis and avoid applying 2SLS-IV tests as our main analysis method here. Since college opening could potentially operate through non-own-education channel to improve mortality outcomes, the exclusion restriction assumption will be violated.
} 
residential house value and father's wage (column 3), and mother fixed effects (column 4). The sibling strategy reported in column 4 -which compares the age-at-death of different siblings to the same mother who aged 17 in different years relative to a college expansion- suggests that after accounting for unobserved time-invariant family characteristics the effects could be even larger in magnitude than the min results $(0.19$ versus 0.13$)$.

While in the main analysis we cluster standard errors at the county of residence level, we show the results when we use Huber-White robust standard errors (column 5) and alternative levels of clustering including birth year, state of residence, and county by birth year level (columns 6-8). In columns 9-13, we add various additional controls and fixed effects. Adding a polynomial function of county population (county of residence when the individual turns age 17) only slightly change the marginal effects (column 9). Adding a county-specific quadratic trend in birth year drops the marginal effect of 4-year college by about 36 percent (column 10). The coefficients are similar when we add birth-month-by-birth-year fixed effects to account for seasonalities in birth outcomes that may appear in later-life health as well as birth-month fixed effects to account for seasonality in mortality (columns 11 and 12). The effect of 4-year college drops by roughly one third when we add a region-by-birth-year fixed effect (column 13).

As mentioned in Currie and Moretti (2003a), while the Integrated Postsecondary Education Data System (IPEDS) is one primary source of college data, some colleges are not reported in this database. ${ }^{11}$ Column 14 shows that eliminating those colleges that are not in the IPEDS listing leads to quite similar effects $(0.125$ verus 0.132$)$. Moreover, not all colleges in our sample grant a degree. Column 15 suggests that focusing only on colleges that grant at least an associate degree produces

\footnotetext{
${ }^{11}$ Roughly 1.2 percent of 4-year colleges and 23 percent of 2-year colleges in our data are not reported and their information is not collected by IPEDS listing.
} 
similar coefficients. Decomposing the colleges by public-private status reveals somewhat heterogeneous effects. The 4-year college coefficient increases by 20 percent when we look at public colleges and remain similar to the main results for private colleges (column 16 and 17). Additional tests are related to functional form checks in which we report semi-log and log-log specifications (columns 18-20). In column 21, we change the unit of the outcome from age in months to age in years as there could potentially be some seasonality factors associated with death not fully captured by death month fixed effects (column 11, ) that have differential effects on mortality by education. The magnitude of 4-year college points to virtually the same effect as the main results.

\subsection{First Stage Effects}

The results so far suggest a consistent and robust reduced-form effect of college openings on later-life mortality. The next step is to explore whether or not college openings increased educational outcomes and if so, to quantify the first stage effects of college openings on education. The Numident data does not report the education or other labor market outcomes of the deceased. One possible approach to estimate the first stage of college openings on educational attainment is to turn to 1960 5\% Decennial Census, as it has detailed information on completed education as well as income, most of the 1923-1940 cohorts have completed their education by 1960 . The main disadvantage of this data is that the county identifier is not available in the public use version and instead, it reports Public Use Microdata Area (PUMA). In addition, IPUMS de-identifies counties based on other geographic variables (including PUMA) and details about location characteristics. In the 1960 census, there are 1,344 PUMAs, and IPUMS de-identifies 435 counties. A PUMA is primarily defined based on the population of an area. In low populated areas (usually rural areas), a PUMA contains several counties while in high populated areas (usually urban areas) a county contains several PUMAs. Therefore, we aggregate college counts at areas where PUMAs cover 
several counties and use county-level college counts for areas where several PUMAs are included in a large county, conditioning on the fact that the county is de-identified by IPUMS. ${ }^{12}$ Therefore, the variation in college expansions across areas is based on a combination of PUMA and county. Using this method, we can merge college data with the 1960 sample and have a match rate of about 97 percent. We drop respondents below age 22 as the primary outcome of interest is a college education. To mitigate migration issues, we implement two additional sample selection criteria. First, we use the information of state of residence 5 years ago (available in the 1960 census) to exclude those individuals whose current state of residence is different from their residence 5 years earlier. Second, we restrict the sample to respondents below age 30 in the year 1960. This leaves us with 341,834 observations. We implement regressions introduced in equation 1 while adding a PUMA-county fixed effect and trend. The results are reported in Table 6 for different outcomes in columns. An additional 4-year college raises the probability of having any college education by over 1 percentage point (column 1), equivalent to an increase of roughly 5.3 percent from the mean of the outcome. The effect of 2-year college is smaller in magnitude and imprecisely estimated. To compare these two coefficients, we focus on the elasticities (reported at the end of columns). A 10 percent increase in the number of 4-year and 2-year colleges raises any college education by 2.3 and 0.04 percent, respectively. The larger effect of 4-year versus 2-year colleges can also be observed at the elasticities for the years of schooling as the outcome (column 5), where the marginal effect of 4-year college is as large as three times the insignificant marginal effect of 2year college. This pattern is also observed on log of wage and salary income (column 7) and $\log$ of total income (column 8). The effects of 4-year college expansion is statistically significant and relatively larger than the insignificant effects of 2-year college opening. An additional 4-year

\footnotetext{
${ }^{12}$ For instance, Los Angeles County consists of 45 PUMAs in 1960 census.
} 
college is associated with approximately 3.8 percent rise in total income (significant at 5 percent level) while the 2-year college effects are quite small and statistically insignificant. One possible reason for small and imprecise estimations of 2-year college is that we are observing these individuals at younger ages than the age range over which the labor market returns of college education would appear. The overall picture reveals the positive effects of college opening on college education and possibly labor market outcomes with larger effects for 4-year college expansions.

\subsection{A Discussion on the Magnitude of the Main Results}

The results so far suggest that college expansions have long-run longevity gains and that these gains are primarily driven by 4-year college expansions. These point estimates and larger effects of 4-year college expansions in Table 4 are also in line with the first stage results of Table 6. They suggest that college expansions (and specifically 4-year college openings) increase college education and possibly total income, and through these channels, they positively affect the longevity of individuals. If this story is true, we can combine the first stage results (column 1, Table 6) with the main results (column 3, Table 4) and convert the Intent-to-Treat effects into Treatment-on-Treated effects. A back-of-the-envelope calculation suggests that an additional 4year college raises the age-at-death of those who would have otherwise not attended college by about 12 months. This is smaller than the effects of college education on life expectancy reported by Lacroix et al. (2019b) who found that college education raises longevity at age 51 by about 49 months.

To add to the TOT effect calculation, we also implement a two-sample two-stage least-square regression by using the information of completed education from the 1960 census and the information on mortality from 1940-census-Numident sample. We aggregate the college counts at the PUMA-county level following the same method as in the first stage results (section 5.3). We 
apply a two-sample SLS method that includes birth cohort fixed effects, PUMA-county fixed effects, PUMA-county trend, and individual controls. The results are reported in Appendix C. In the fully specified model, having at least a college degree is associated with roughly 20 months higher age-at-death. We also note that measurement error in the first stage analysis as well as the two-sample 2SLS framework (which uses PUMA-county rather than county linkages) would likely attenuate our coefficients and therefore would suggest smaller treatment on the treated effects.

\subsection{Heterogeneity of the Results: Heterogeneity by Gender-Race/Ethnicity.}

In Table 7, we explore how the effects vary over demographic characteristics by

interacting with college counts a dummy for female, other races, black, and Hispanic (columns $1-4$, in order). The mortality effect of 4-year and 2-year colleges is 0.03 and 0.06 months larger for males than females. The marginal effects of 4-year and 2-year colleges are larger among people of other races/ethnicities (Native Americans, Chinese, Japanese, and 'other' Asian-Pacific Islanders versus whites and blacks) by 0.08 and 0.03 months, respectively, although both coefficients are imprecisely estimated. Among blacks, the mortality gains from 2-year college opening are significantly larger than other races, by 0.12 additional months. On the other hand, the mortality gains from 2-year colleges are more pronounced among non-Hispanics than Hispanic people. We observe similar heterogeneity patterns in the first stage results when we interact the gender/race dummies with measures of college expansion and replace the outcome with various measures of college education using the 1960 census data. These results are reported in Appendix D. The effects of 4-year college expansion are more pronounced among males for all measures of college education. The marginal effects of both 4-year and 2-year college openings are slightly (and insignificantly) larger among other races in comparison with blacks and whites. This consistent pattern between the first stage effects and reduced-form effects also holds when we look at differential effects among blacks versus non-blacks. The 4- 
year college effects are larger among non-blacks while the effects of 2-year colleges are larger among blacks (compare with the results in Table 7).

Heterogeneity across Subsamples. We investigate the heterogeneity of the results across subsamples based on other observable dimensions in Table 8 . We divide the sample by individuals' census region of residence in 1940 (columns 1-4), birth cohort (columns 5-6), father's education (columns 7-8), and county population (columns 9-10).

Compared to the main results (column 3, Table 4), the effect of 4-year college is larger by a factor of 2 in Midwest region. It drops by roughly 60 percent for South and West regions and becomes negative and converges to zero for Northeast region. The effects of 2-year college counts become considerably larger for Northeast, Midwest, and South regions. In southern states, an additional 2-year college is associated with 0.35 months higher age at death, almost 7.5 times larger than its aggregate effect in the main results. Both 4-year and 2-year college expansions are more effective for later cohorts than earlier cohorts. The effect of 2-year college expansions among cohorts born after 1932 is not only larger than the main results (by a factor of 6.5) but also statistically significant at 10 percent level. Not surprisingly, the college expansion is more effective for individuals whose father is more educated. Finally, low population counties benefit more from 4-year college expansions although the marginal effects are not precise and significant at 10 percent level (column 9 vs column 10).

Heterogeneity in $2 \times 2$ Difference-in-Difference (DD) Estimate. The empirical strategy of equation 1 operates as a difference-in-difference (DD) model that compares the outcome of cohorts with higher versus lower exposure to college expansions (treatment). However, the OLS estimation of the DD estimator in a two-way fixed effect framework, that the treated group receives the treatment at different points of time (in comparison to a pre-post and treatment-control DD 
estimation), compares the outcome of all combinations of two-by-two treatment-control/pre-post pairs. The least-square coefficient is finally a weighted average of all these comparisons with the weights in the proportion of how long the pair had received the treatment and also the variance of the treatment (Goodman-Bacon, 2021). For instance, the OLS compares the outcomes of those cohorts who lived in counties that experienced an expansion to those in counties with no colleges at all (treatment vs never treated), it compares the outcomes of those who experienced a college expansion to those that had an expansion earlier and no new expansion after that (later treatment vs earlier control), and those who had an expansion earlier versus those who had later (earlier treatment vs later control). To explore this pairwise heterogeneity of the OLS-produced DD estimation, we implement bacon-decomposition which shows the coefficients of the pairwise DD estimates for 4-year colleges on age-at-death against their respective weights. In so doing, we collapse the data at the county by birth cohort level and assigned a dummy for treatment based on exposure to a college opening. ${ }^{13}$ The results are reported in Figure 5. While there is heterogeneity in the pairwise DD coefficients, all three types of comparisons reveal positive effects. The largest weight is assigned to the comparisons between those with a college expansion versus those with no colleges in their county (weight $=0.92$, DD-coefficient $=0.26$ ). Comparing earlier expansions as the treatment to later expansions as the control group (weight $=0.04$, DD-coefficient $=0.41$ ) or comparing later expansions as treatment and earlier expansions as control (weight $=0.04$, DDcoefficient $=0.26$ ) reveal average DD coefficients that are quite close to the treated-vs-never-treated comparison as well as the overall DD estimation $(=0.266)$. Therefore, though the OLS effects of

\footnotetext{
${ }^{13}$ To implement this analysis, we assigned a dummy for treatment that takes a value of one if the county experienced a new opening from year $t \mathrm{t}$ to year $t-1$ and zero otherwise.
} 
DD estimation reveals various effects that are sometimes negative, there is no evidence to suggest that the main results are driven by one specific type of comparison.

\section{Conclusion and Policy Implications}

The benefits of education, as shown by a large body of literature, can go beyond its labor market returns. This study investigated the potential long term effects of college expansion on mortality and longevity. Our results shed new light on the long-run health benefits of education and add to the literature on social returns of education and, specifically, college education. We found that a new 4-year college construction in the local area increases any college education by about 5.2 percent from the mean and adds to the average schooling by 0.09 additional years. It also contributes to age-at-death by about 0.13 months. A back-of-an-envelope calculation suggests that the effects could be as large as 12 months for those who do attend a 4-year college after a college opening and would have not attended if the college had not been constructed.

An event-study analysis showed that for unaffected cohorts college expansions had no effects, reducing concerns over pre-trends in the outcome, while the effects start to rise for the affected cohorts, those younger than 17 at the time of college expansion. We also explored whether the county-expansion-induced migration of possibly college-educated cohorts to collegeexpanding counties has driven our results by regressing the observable characteristics of individuals on college counts. The evidence is not consistent and strong enough to point to this selective migration. Moreover, a series of placebo tests, in which we assign the measure of colleges to individuals in ages later than 17 , supports our empirical method.

To illustrate the contribution of college expansion to longevity of the US population, we extrapolate our findings to the second half of twentieth century college openings and mortality trends. Between the years 1940 to 1990, there has been 489 new 4-year college construction across 
US counties. The share of local area (own and neighboring county) that were affected by the expansion accounts for 0.4 percent of the US population. Between the years 1970-2018, the average age at death, conditional on survival up to age 47 , increased from 72.19 to 77.09 years. ${ }^{14}$ Considering the fact that college educated individuals accounted for 18.5 percent of deaths and implementing the results of Table 4 and first stage results of Table 6 , one can calculate that the 1940-1990 college expansions increased average age at death for the whole US population by 4.35 months. This is equivalent to 7.5 percent of the observed increase in the longevity trend between the years $1970-2018 .^{15}$

\footnotetext{
${ }^{14}$ We look at this time period rather than 1940-1990 (period of college expansion calculation) since we have assigned college expansion at age 17 and we restrict our attention to those aged at least 47, per Numident death coverage. This means that the earlier cohort that we observe must have been 17 years old in 1940 and have reached age 47, which points to a mortality window starting at 1970 .

${ }^{15}$ Since the effects of Table 4 are local average treatment effects, which shows the changes in outcome for those in local areas rather than the whole population, we need to multiply the effects by the share of locally affected population to the whole US population. The final number is calculated as the product of total new college construction (489), the inverse value of first stage effect (1/0.0108), the main effect of 4-year college on longevity (0.1318), the share of college educated people in death records (0.185), and the average share of local population to the whole US population over the same period (0.004).
} 


\section{References}

Albouy, V., \& Lequien, L. (2009). Does compulsory education lower mortality? Journal of Health Economics, 28(1), 155-168. https://doi.org/10.1016/J.JHEALECO.2008.09.003

Bautista, M. A., González, F., Martinez, L. R., Munoz, P., \& Prem, M. (2020). Does Higher Education Reduce Mortality? Evidence from a Natural Experiment. SSRN Electronic Journal. https://doi.org/10.2139/SSRN.3717849

Behrman, J. R., Kohler, H.-P., Jensen, V. M., Pedersen, D., Petersen, I., Bingley, P., \& Christensen, K. (2011). Does More Schooling Reduce Hospitalization and Delay Mortality? New Evidence Based on Danish Twins. Demography, 48(4), 1347-1375. https://doi.org/10.1007/S13524011-0052-1

Black, D. A., Hsu, Y. C., \& Taylor, L. J. (2015). The effect of early-life education on later-life mortality. Journal of Health Economics, 44, 1-9. https://doi.org/10.1016/J.JHEALECO.2015.07.007

Buckles, K., Hagemann, A., Malamud, O., Morrill, M., \& Wozniak, A. (2016). The effect of college education on mortality. Journal of Health Economics, 50, 99-114. https://doi.org/10.1016/J.JHEALECO.2016.08.002

Campbell, F., Conti, G., Heckman, J. J., Moon, S. H., Pinto, R., Pungello, E., \& Pan, Y. (2014). Early Childhood Investments Substantially Boost Adult Health. Science, 343(6178), 14781485. https://doi.org/10.1126/SCIENCE.1248429

Clark, D., \& Royer, H. (2013). The Effect of Education on Adult Mortality and Health: Evidence from Britain. American Economic Review, 103(6), 2087-2120. https://doi.org/10.1257/AER.103.6.2087

Conti, G., Heckman, J. J., \& Pinto, R. (2016). The Effects of Two Influential Early Childhood Interventions on Health and Healthy Behaviour. The Economic Journal, 126(596), F28--F65. https://doi.org/10.1111/ECOJ.12420

Conti, G., Heckman, J., \& Urzua, S. (2010). The Education-Health Gradient. American Economic Review, 100(2), 234-238. https://doi.org/10.1257/AER.100.2.234

Currie, J., \& Moretti, E. (2003). Mother's Education and the Intergenerational Transmission of Human Capital: Evidence from College Openings. The Quarterly Journal of Economics, 118(4), 1495-1532. https://doi.org/10.1162/003355303322552856

Everett, B. G., Rehkopf, D. H., \& Rogers, R. G. (2013). The Nonlinear Relationship Between Education and Mortality: An Examination of Cohort, Race/Ethnic, and Gender Differences. Population Research and Policy Review 2013 32:6, 32(6), 893-917. https://doi.org/10.1007/S11113-013-9299-0

Fischer, M., Karlsson, M., \& Nilsson, T. (2013). Effects of Compulsory Schooling on Mortality: Evidence from Sweden. International Journal of Environmental Research and Public Health 2013, Vol. 10, Pages 3596-3618, 10(8), 3596-3618. https://doi.org/10.3390/IJERPH10083596

Fletcher, J. M. (2015). New evidence of the effects of education on health in the US: Compulsory schooling laws revisited. Social Science \& Medicine, 127, 101-107. https://doi.org/10.1016/J.SOCSCIMED.2014.09.052

Fletcher, J. M., \& Frisvold, D. E. (2011). College selectivity and young adult health behaviors. Economics of Education Review, 30(5), 826-837. 
https://doi.org/10.1016/J.ECONEDUREV.2011.04.005

Fletcher, J. M., \& Frisvold, D. E. (2014). The long run health returns to college quality. Review of Economics of the Household, 12(2), 295-325. https://doi.org/10.1007/S11150-012-9150-0

Fruehwirth, J. C. (2014). Can Achievement Peer Effect Estimates Inform Policy? A View from Inside the Black Box. The Review of Economics and Statistics, 96(3), 514-523. https://doi.org/10.1162/REST_A_00385

Galama, T. J., Lleras-Muney, A., \& van Kippersluis, H. (2018). The Effect of Education on Health and Mortality: A Review of Experimental and Quasi-Experimental Evidence. https://doi.org/10.3386/W24225

Gathmann, C., Jürges, H., \& Reinhold, S. (2015). Compulsory schooling reforms, education and mortality in twentieth century Europe. Social Science \& Medicine, 127, 74-82. https://doi.org/10.1016/J.SOCSCIMED.2014.01.037

Goldstein, J. R., Alexander, M., Breen, C., Miranda González, A., Menares, F., Osborne, M., Snyder, M., \& Yildirim, U. (2021). Censoc Project. In CenSoc Mortality File: Version 2.0. Berkeley: University of California. https://censoc.berkeley.edu/data/

Goodman-Bacon, A. (2021). Difference-in-differences with variation in treatment timing. Journal of Econometrics. https://doi.org/10.1016/J.JECONOM.2021.03.014

Halpern-Manners, A., Helgertz, J., Warren, J. R., \& Roberts, E. (2020). The Effects of Education on Mortality: Evidence From Linked U.S. Census and Administrative Mortality Data. Demography, 57(4), 1513-1541. https://doi.org/10.1007/S13524-020-00892-6

Heckman, J., Pinto, R., \& Savelyev, P. (2013). Understanding the Mechanisms through Which an Influential Early Childhood Program Boosted Adult Outcomes. American Economic Review, 103(6), 2052-2086. https://doi.org/10.1257/AER.103.6.2052

Jaffe, D. H., Eisenbach, Z., Neumark, Y. D., \& Manor, O. (2006). Effects of husbands' and wives' education on each other's mortality. Social Science \& Medicine, 62(8), 2014-2023. https://doi.org/10.1016/J.SOCSCIMED.2005.08.030

Jemal, A., Thun, M. J., Ward, E. E., Henley, S. J., Cokkinides, V. E., \& Murray, T. E. (2008). Mortality from Leading Causes by Education and Race in the United States, 2001. American Journal of Preventive Medicine, 34(1), 1--8.e7. https://doi.org/10.1016/J.AMEPRE.2007.09.017

Kalediene, R., \& Petrauskiene, J. (2005). Inequalities in mortality by education and socioeconomic transition in Lithuania: equal opportunities? Public Health, 119(9), 808-815. https://doi.org/10.1016/J.PUHE.2004.11.004

Kippersluis, H. van, O’Donnell, O., \& Doorslaer, E. van. (2011). Long-Run Returns to Education. Journal of Human Resources, 46(4), 695-721. https://doi.org/10.3368/JHR.46.4.695

Kravdal, Ø. (2008). A broader perspective on education and mortality: Are we influenced by other people's education? Social Science \& Medicine, 66(3), 620-636. https://doi.org/10.1016/J.SOCSCIMED.2007.10.009

Lacroix, G., Laliberté-Auger, F., Michaud, P.-C., \& Parent, D. (2019). The effect of college education on health and mortality: Evidence from Canada. https://doi.org/10.1002/hec.3975

Lager, A. C. J., \& Torssander, J. (2012). Causal effect of education on mortality in a quasiexperiment on 1.2 million Swedes. Proceedings of the National Academy of Sciences, 109(22), 8461-8466. https://doi.org/10.1073/PNAS.1105839109

Lleras-Muney, A. (2005). The Relationship Between Education and Adult Mortality in the United States. The Review of Economic Studies, 72(1), 189-221. https://doi.org/10.1111/0034- 
6527.00329

Lleras-Muney, A., Price, J., \& Yue, D. (2020). The Association Between Educational Attainment and Longevity using Individual Level Data from the 1940 Census. https://doi.org/10.3386/W27514

Lundborg, P., Lyttkens, C. H., \& Nystedt, P. (2016). The Effect of Schooling on Mortality: New Evidence From 50,000 Swedish Twins. Demography, 53(4), 1135-1168. https://doi.org/10.1007/S13524-016-0489-3

Lynch, S. M. (2003). Cohort and life-course patterns in the relationship between education and health: A hierarchical approach. Demography 2003 40:2, 40(2), 309-331. https://doi.org/10.1353/DEM.2003.0016

Madsen, M., Andersen, A.-M. N., Christensen, K., Andersen, P. K., \& Osler, M. (2010). Does Educational Status Impact Adult Mortality in Denmark? A Twin Approach. American Journal of Epidemiology, 172(2), 225-234. https://doi.org/10.1093/AJE/KWQ072

Martins, P. S., \& Jin, J. Y. (2008). Firm-level social returns to education. Journal of Population Economics 2008 23:2, 23(2), 539-558. https://doi.org/10.1007/S00148-008-0204-9

Mazumder, B. (2008). Does education improve health? A reexamination of the evidence from compulsory schooling laws. Economic Perspectives, 32(Q II), 2-16.

Mazzonna, F. (2014). The long lasting effects of education on old age health: Evidence of gender differences. Social Science \& Medicine, 101, 129-138. https://doi.org/10.1016/J.SOCSCIMED.2013.10.042

Meara, E. R., Richards, S., \& Cutler, D. M. (2017). The Gap Gets Bigger: Changes In Mortality And Life Expectancy, By Education, 1981-2000. Https://Doi.Org/10.1377/Hlthaff.27.2.350, 27(2), 350-360. https://doi.org/10.1377/HLTHAFF.27.2.350

Meghir, C., Palme, M., \& Simeonova, E. (2018). Education and Mortality: Evidence from a Social Experiment. American Economic Journal: Applied Economics, 10(2), 234-256. https://doi.org/10.1257/APP.20150365

Oreopoulos, P., \& Salvanes, K. G. (2011). Priceless: The Nonpecuniary Benefits of Schooling. Journal of Economic Perspectives, 25(1), 159-184. https://doi.org/10.1257/JEP.25.1.159

Ross, C. E., Masters, R. K., \& Hummer, R. A. (2012). Education and the Gender Gaps in Health and Mortality. Demography, 49(4), 1157-1183. https://doi.org/10.1007/S13524-012-0130-Z

Ruggles, S., Flood, S., Goeken, R., Grover, J., \& Meyer, E. (2020). IPUMS USA: Version 10.0 [dataset]. Minneapolis, MN: IPUMS. https://doi.org/10.18128/D010.V10.0

Spoerri, A., Schmidlin, K., Richter, M., Egger, M., \& Clough-Gorr, K. M. (2014). Individual and spousal education, mortality and life expectancy in Switzerland: a national cohort study. $J$ Epidemiol Community Health, 68(9), 804-810. https://doi.org/10.1136/JECH-2013-203714

van Kippersluis, H., O'Donnell, O., \& van Doorslaer, E. (2011). Long-Run Returns to Education. Journal of Human Resources, 46(4), 695-721. https://doi.org/10.3368/JHR.46.4.695

Zajacova, A. (2006). Education, gender, and mortality: Does schooling have the same effect on mortality for men and women in the US? Social Science \& Medicine, 63(8), 2176-2190. https://doi.org/10.1016/J.SOCSCIMED.2006.04.031 


\section{Tables}

Table 1 - Summary Statistics

\begin{tabular}{|c|c|c|c|c|c|}
\hline Variable & Observations & Mean & Std. Dev. & Min & Max \\
\hline Female & $3,849,792$ & 0.426 & 0.4945 & 0 & 1 \\
\hline White & $3,849,792$ & 0.9067 & 0.2908 & 0 & 1 \\
\hline Black & $3,849,792$ & 0.0893 & 0.2852 & 0 & 1 \\
\hline Hispanic & $3,849,792$ & 0.0182 & 0.1335 & 0 & 1 \\
\hline First Generation Immigrant & $3,849,792$ & 0.0034 & 0.0578 & 0 & 1 \\
\hline Second-generation Immigrant & $3,849,792$ & 0.1446 & 0.3517 & 0 & 1 \\
\hline Birth Year & $3,849,792$ & 1929.293 & 4.7755 & 1923 & 1940 \\
\hline Death Year & $3,849,792$ & 1998.5607 & 4.6756 & 1988 & 2005 \\
\hline Death Age (Years) & $3,849,792$ & 68.7814 & 6.2309 & 47 & 82 \\
\hline Death Age (Months) & $3,849,792$ & 831.3591 & 74.7004 & 565 & 995 \\
\hline \multicolumn{6}{|c|}{ 4-Year Colleges (Own+Neighboring): } \\
\hline Total & $3,849,792$ & 11.7987 & 14.8451 & 0 & 63 \\
\hline Not in IPEDS List & $3,849,792$ & 11.6559 & 14.6745 & 0 & 63 \\
\hline $\begin{array}{l}\text { Not Granting at Least Associate } \\
\text { Degree }\end{array}$ & $3,849,792$ & 11.5155 & 14.3269 & 0 & 60 \\
\hline Private & $3,849,792$ & 2.4138 & 2.5338 & 0 & 13 \\
\hline Public & $3,849,792$ & 9.0399 & 12.3974 & 0 & 53 \\
\hline \multicolumn{6}{|c|}{ 2-Year Colleges (Own+Neighboring): } \\
\hline Total & $3,849,792$ & 3.4337 & 5.9778 & 0 & 44 \\
\hline Not in IPEDS List & $3,849,792$ & 2.6455 & 5.0074 & 0 & 40 \\
\hline $\begin{array}{l}\text { Not Granting at Least Associate } \\
\text { Degree }\end{array}$ & $3,849,792$ & 2.6713 & 5.0598 & 0 & 40 \\
\hline Private & $3,849,792$ & 1.4873 & 4.3511 & 0 & 38 \\
\hline Public & $3,849,792$ & 1.1234 & 2.1722 & 0 & 14 \\
\hline 4-Year College (Own County) & $3,849,792$ & 3.1103 & 5.0768 & 0 & 26 \\
\hline 2-Year College (Own County) & $3,849,792$ & .9759 & 2.3556 & 0 & 18 \\
\hline
\end{tabular}

Notes. 
Table 2 - Endogenous Migration: College Expansion and Endogenous Changes in Demographic and Socioeconomic Characteristics of Individuals

\begin{tabular}{|c|c|c|c|c|c|c|c|}
\hline & \multicolumn{7}{|c|}{ Outcome: } \\
\hline & Female & White & Black & Hispanic & $\begin{array}{l}\text { Mother's } \\
\text { Years of } \\
\text { Schooling }\end{array}$ & $\begin{array}{l}\text { Father's } \\
\text { Years of } \\
\text { Schooling }\end{array}$ & $\begin{array}{c}\text { Family SEI } \\
\text { Score }\end{array}$ \\
\hline & $(1)$ & $(2)$ & (3) & $(4)$ & $(5)$ & $(6)$ & $(7)$ \\
\hline \multicolumn{8}{|c|}{ Panel A. County and Birth Cohort FE } \\
\hline 4-Year & -0.00001 & -0.00049 & 0.00065 & 0.0013 & $0.09736 * * *$ & $0.11161 * * *$ & $-0.16778 * *$ \\
\hline College & $(0.00083)$ & $(0.00101)$ & $(0.00095)$ & $(0.00091)$ & $(0.03323)$ & $(0.03547)$ & (0.07409) \\
\hline 2-Year & 0.00113 & $0.00202 * *$ & -0.00126 & $0.00102 *$ & 0.04205 & 0.04438 & -0.11867 \\
\hline College & $(0.00101)$ & $(0.00094)$ & $(0.00077)$ & $(0.00056)$ & $(0.05122)$ & $(0.05455)$ & $(0.07944)$ \\
\hline Observations & 3855600 & 3855600 & 3855600 & 3855600 & 3543964 & 3308720 & 3611645 \\
\hline R-squared & 0.00344 & 0.23268 & 0.24211 & 0.25398 & 0.12994 & 0.13006 & 0.01839 \\
\hline Mean DV & 0.43 & 0.91 & 0.09 & 0.02 & 8.18 & 7.78 & 3.16 \\
\hline \multicolumn{8}{|c|}{ Panel B. County and Birth Cohort FE + County by Birth Cohort Trend } \\
\hline 4-Year & $0.0026^{* *}$ & -0.00068 & 0.00032 & -0.00027 & 0.00445 & 0.00627 & 0.01953 \\
\hline College & $(0.00104)$ & $(0.00062)$ & $(0.0006)$ & $(0.0014)$ & $(0.01287)$ & $(0.01103)$ & $(0.02482)$ \\
\hline 2-Year & 0.00033 & -0.00089 & 0.00078 & -0.00019 & -0.01918 & -0.0077 & -0.03119 \\
\hline College & $(0.00118)$ & $(0.00061)$ & $(0.00056)$ & $(0.00081)$ & $(0.01225)$ & $(0.00873)$ & $(0.02751)$ \\
\hline Observations & 3855600 & 3855600 & 3855600 & 3855600 & 3543964 & 3308720 & 3611645 \\
\hline R-squared & 0.00442 & 0.23462 & 0.24401 & 0.25585 & 0.134 & 0.1337 & 0.0197 \\
\hline Mean DV & 0.43 & 0.91 & 0.09 & 0.02 & 8.18 & 7.78 & 3.16 \\
\hline
\end{tabular}


Table 3 - Placebo Tests: Assigning Colleges at Ages Later than 17

\begin{tabular}{|c|c|c|c|c|c|c|c|c|c|}
\hline & \multicolumn{9}{|c|}{ Outcome: Age-at-death (Months) } \\
\hline & \multicolumn{3}{|c|}{ Colleges Assigned at Age 25} & \multicolumn{3}{|c|}{ Colleges Assigned at Age 30} & \multicolumn{3}{|c|}{ Colleges Assigned at Age 35} \\
\hline & $(1)$ & $(2)$ & (3) & (4) & $(5)$ & $(6)$ & $(7)$ & $(8)$ & (9) \\
\hline $\begin{array}{l}\text { 4-Year } \\
\text { College }\end{array}$ & $\begin{array}{c}0.0414 \\
(0.0508)\end{array}$ & $\begin{array}{c}0.0414 \\
(0.0562)\end{array}$ & $\begin{array}{c}-0.0882 \\
(0.0551)\end{array}$ & $\begin{array}{c}0.0549 \\
(0.0485)\end{array}$ & $\begin{array}{c}0.0504 \\
(0.0528)\end{array}$ & $\begin{array}{c}-0.0249 \\
(0.0692)\end{array}$ & $\begin{array}{c}0.0538 \\
(0.0406)\end{array}$ & $\begin{array}{c}0.0549 \\
(0.0445)\end{array}$ & $\begin{array}{c}0.0306 \\
(0.0643)\end{array}$ \\
\hline $\begin{array}{l}\text { 2-Year } \\
\text { College }\end{array}$ & $\begin{array}{c}0.0676^{*} \\
(0.035)\end{array}$ & $\begin{array}{c}0.0762 * * \\
(0.0366)\end{array}$ & $\begin{array}{l}-0.0646 \\
(0.0627)\end{array}$ & $\begin{array}{c}0.0348 \\
(0.0279)\end{array}$ & $\begin{array}{c}0.0446 \\
(0.0294)\end{array}$ & $\begin{array}{c}-0.0764 * \\
(0.0406)\end{array}$ & $\begin{array}{c}0.0386 \\
(0.0283)\end{array}$ & $\begin{array}{c}0.0423 \\
(0.0299)\end{array}$ & $\begin{array}{c}0.0321 \\
(0.0359)\end{array}$ \\
\hline $\begin{array}{l}\text { Observations } \\
\text { R-squared } \\
\text { Mean DV }\end{array}$ & $\begin{array}{c}3849792 \\
0.4448 \\
831.4\end{array}$ & $\begin{array}{c}3849792 \\
0.4469 \\
831.4\end{array}$ & $\begin{array}{c}3849792 \\
0.4474 \\
831.4\end{array}$ & $\begin{array}{c}3849792 \\
0.4448 \\
831.4\end{array}$ & $\begin{array}{c}3849792 \\
0.4469 \\
831.4\end{array}$ & $\begin{array}{c}3849792 \\
0.4474 \\
831.4\end{array}$ & $\begin{array}{c}3849792 \\
0.4448 \\
831.4\end{array}$ & $\begin{array}{c}3849792 \\
0.4469 \\
831.4\end{array}$ & $\begin{array}{c}3849792 \\
0.4474 \\
831.4\end{array}$ \\
\hline County FE & Yes & Yes & Yes & Yes & Yes & Yes & Yes & Yes & Yes \\
\hline $\begin{array}{l}\text { Birth Cohort } \\
\text { FE }\end{array}$ & Yes & Yes & Yes & Yes & Yes & Yes & Yes & Yes & Yes \\
\hline $\begin{array}{l}\text { Individual } \\
\text { Controls }\end{array}$ & No & Yes & Yes & No & Yes & Yes & No & Yes & Yes \\
\hline $\begin{array}{l}\text { County by } \\
\text { Birth Cohort } \\
\text { Linear Trend }\end{array}$ & No & No & Yes & No & No & Yes & No & No & Yes \\
\hline
\end{tabular}


Table 4 - Main Results: College Expansion and Age-at-death

\begin{tabular}{lccc}
\hline & \multicolumn{3}{c}{ Outcome: Death Age (Months) } \\
\cline { 2 - 4 } & $(1)$ & $(2)$ & $(3)$ \\
\hline 4-Year College & $0.1922^{* * *}$ & $0.2029^{* * *}$ & $0.1318^{* *}$ \\
2-Year College & $(0.0445)$ & $(0.0462)$ & $(0.0671)$ \\
& -0.0233 & -0.0278 & 0.0473 \\
Female & $(0.0605)$ & $(0.066)$ & $(0.0539)$ \\
Other & & $6.6777^{* * *}$ & $6.6864^{* * *}$ \\
& & $(0.0892)$ & $(0.0894)$ \\
Black & & $-2.6102^{* * *}$ & $-2.6399^{* * *}$ \\
& & $(0.5485)$ & $(0.5493)$ \\
Hispanic & & $-3.8^{* * *}$ & $-3.8327^{* * *}$ \\
& & $(0.1204)$ & $(0.1209)$ \\
First Generation Immigrant & & 0.2661 & 0.2797 \\
& & $(0.2815)$ & $(0.2851)$ \\
Second-generation Immigrant & & $1.4886 * *$ & $1.5458^{* * *}$ \\
& & $(0.5854)$ & $(0.5818)$ \\
& & $0.7931^{* * *}$ & $0.8181^{* * *}$ \\
Observations & & $(0.1084)$ & $(0.1086)$ \\
R-squared & & & \\
Mean DV & & 3849792 & 3849792 \\
Elasticity of 4-Year College & 3849792 & 0.4469 & 0.4474 \\
Elasticity of 2-Year College & 0.4448 & 831.4 & 831.4 \\
County FE & 831.4 & 0.00288 & 0.00187 \\
Birth Cohort FE & 0.00273 & -0.00011 & 0.00020 \\
Individual Controls & -0.00009 & Yes & Yes \\
County by Birth Cohort Linear Trend & Yes & Yes & Yes \\
\hline & No & Yes & Yes \\
\hline
\end{tabular}

Note. Each column represents a separate regression. Individual controls include dummies for female, white, black, Hispanic, first-generation immigrant, and second-generation immigrant. Standard errors, clustered at the county level, are in parentheses.

$* * * p<.01, * * p<.05, * p<.1$ 
Table 5 - Robustness Checks of College Expansion and Age-at-death

\begin{tabular}{|c|c|c|c|c|c|c|c|}
\hline & Column 3 Table 4 & $\begin{array}{c}\text { Adding Mother- } \\
\text { Father } \\
\text { Schooling+Family } \\
\text { SEI Score } \\
\end{array}$ & $\begin{array}{c}\text { Adding } \\
\text { House } \\
\text { Value+Father } \\
\text { Wage } \\
\end{array}$ & $\begin{array}{c}\text { Adding } \\
\text { Mother Fixed } \\
\text { Effect } \\
\end{array}$ & $\begin{array}{c}\text { Huber-White } \\
\text { Robust SE }\end{array}$ & $\begin{array}{l}\text { SE clustered } \\
\text { at Birth } \\
\text { Cohort } \\
\end{array}$ & $\begin{array}{c}\text { SE } \\
\text { clustered } \\
\text { at state- } \\
\text { level } \\
\end{array}$ \\
\hline & (1) & (2) & (3) & (4) & (5) & (6) & (7) \\
\hline 4-Year & $0.1318 * *$ & $0.1557 * *$ & 0.1476 & 0.1933 & $0.1318 * *$ & $0.1318 * *$ & $0.1318 * *$ \\
\hline College & $(0.0671)$ & $(0.0718)$ & $(0.1053)$ & $(0.2181)$ & $(0.0626)$ & $(0.0601)$ & $(0.0608)$ \\
\hline 2-Year & 0.0473 & -0.0008 & -0.048 & -0.0765 & 0.0473 & 0.0473 & 0.0473 \\
\hline College & $(0.0539)$ & $(0.0597)$ & $(0.1031)$ & $(0.2069)$ & $(0.0671)$ & $(0.0478)$ & $(0.0624)$ \\
\hline Observations & 3849792 & 3195730 & 1298744 & 951210 & 3849792 & 3849792 & 3849792 \\
\hline R-squared & 0.4474 & 0.4556 & 0.4293 & 0.6887 & 0.4474 & 0.4474 & 0.4474 \\
\hline \multirow[t]{3}{*}{ Mean DV } & 831.4 & 828.8 & 838.1 & 831.0 & 831.4 & 831.4 & 831.4 \\
\hline & $\begin{array}{l}\text { SE clustered at } \\
\text { county by birth } \\
\text { cohort level }\end{array}$ & $\begin{array}{c}\text { Adding a } \\
\text { polynomial } \\
\text { function of county } \\
\text { population }\end{array}$ & $\begin{array}{c}\text { Adding } \\
\text { County by } \\
\text { Birth Cohort } \\
\text { Quadratic } \\
\text { Trend } \\
\end{array}$ & $\begin{array}{l}\text { Adding Birth } \\
\text { Month by } \\
\text { Birth Year FE }\end{array}$ & $\begin{array}{l}\text { Adding } \\
\text { Month of } \\
\text { Death FE } \\
\end{array}$ & $\begin{array}{c}\text { Adding } \\
\text { Region by } \\
\text { Birth Cohort } \\
\text { FE } \\
\end{array}$ & $\begin{array}{c}\text { Drop } \\
\text { colleges } \\
\text { if not in } \\
\text { IPEDS } \\
\text { list }\end{array}$ \\
\hline & (8) & (9) & (10) & (11) & (12) & (13) & (14) \\
\hline 4-Year & $0.1318^{*}$ & $0.1301 * *$ & 0.0837 & $0.1332 * *$ & $0.1281^{*}$ & 0.084 & $0.1253^{*}$ \\
\hline College & $(0.0744)$ & $(0.0629)$ & $(0.0783)$ & $(0.0672)$ & $(0.0672)$ & $(0.0619)$ & $(0.0672)$ \\
\hline 2-Year & 0.0473 & 0.0602 & 0.0844 & 0.0484 & 0.0475 & 0.0187 & 0.0536 \\
\hline College & $(0.0622)$ & $(0.0579)$ & $(0.0687)$ & $(0.0538)$ & $(0.0547)$ & $(0.0634)$ & $(0.0638)$ \\
\hline Observations & 3849792 & 3849792 & 3849792 & 3849792 & 3849792 & 3849792 & 3849792 \\
\hline R-squared & 0.4474 & 0.4474 & 0.4479 & 0.4491 & 0.4484 & 0.4474 & 0.4474 \\
\hline \multirow[t]{3}{*}{ Mean DV } & 831.4 & 831.4 & 831.4 & 831.4 & 831.4 & 831.4 & 831.4 \\
\hline & $\begin{array}{c}\text { Drop colleges if } \\
\text { not granting at } \\
\text { least an associate } \\
\text { degree }\end{array}$ & Public Colleges & $\begin{array}{c}\text { Private } \\
\text { Colleges }\end{array}$ & $\begin{array}{l}\text { Outcome in } \\
\text { logarithm } \\
\text { (Semi-Log } \\
\text { specification) } \\
\end{array}$ & $\begin{array}{c}\text { Log of } \\
\text { Colleges as } \\
\text { Explanatory } \\
\text { Variable } \\
\end{array}$ & $\begin{array}{c}\text { Log-Log } \\
\text { specification }\end{array}$ & $\begin{array}{c}\text { Replace } \\
\text { Outcome } \\
\text { with } \\
\text { Death } \\
\text { Age in } \\
\text { Years } \\
\end{array}$ \\
\hline & (15) & (16) & (17) & (18) & (19) & $(20)$ & $(21)$ \\
\hline 4-Year & $0.1175^{*}$ & 0.1584 & 0.1343 & $0.0002 * *$ & 0.0335 & 0.0001 & $0.0108^{*}$ \\
\hline College & $(0.07)$ & (0.1289) & $(0.0823)$ & $(0.0001)$ & $(0.2783)$ & $(0.0004)$ & $(0.0056)$ \\
\hline 2-Year & 0.0668 & -0.0046 & 0.1423 & 0.0001 & $0.2854^{*}$ & $0.0004 * *$ & 0.004 \\
\hline College & $(0.0651)$ & $(0.07)$ & $(0.1228)$ & $(0.0001)$ & $(0.146)$ & $(0.0002)$ & $(0.0045)$ \\
\hline Observations & 3534637 & 3488475 & 3849792 & 3849792 & 3849792 & 3849792 & 3849792 \\
\hline R-squared & 0.4605 & 0.4272 & 0.4474 & 0.4489 & 0.4474 & 0.4489 & 0.4465 \\
\hline Mean DV & 828.4 & 824.6 & 831.4 & 6.7 & 831.4 & 6.7 & 68.8 \\
\hline
\end{tabular}


Table 6 - College Expansion and Education-Income at 1960 Census

\begin{tabular}{|c|c|c|c|c|c|c|c|}
\hline & \multicolumn{5}{|c|}{ First Stage Outcomes: } & \multicolumn{2}{|c|}{ Reduced Form Outcomes: } \\
\hline & $\begin{array}{l}\text { Education: At } \\
\text { Least One Year } \\
\text { of College }\end{array}$ & $\begin{array}{l}\text { Education: At } \\
\text { Least Two Years } \\
\text { of College }\end{array}$ & $\begin{array}{l}\text { Education: At } \\
\text { Least Three } \\
\text { Years of College }\end{array}$ & $\begin{array}{c}\text { Education: At } \\
\text { Least Four Years } \\
\text { of College }\end{array}$ & $\begin{array}{l}\text { Years of } \\
\text { Schooling }\end{array}$ & $\begin{array}{l}\text { Log of Wage } \\
\text { Income }\end{array}$ & $\begin{array}{l}\text { Log of Total } \\
\text { Income }\end{array}$ \\
\hline & $(1)$ & $(2)$ & (3) & (4) & (5) & $(7)$ & $(8)$ \\
\hline 4-Year College & $\begin{array}{l}0.0108 * * * \\
(0.0033)\end{array}$ & $\begin{array}{l}0.009 * * * \\
(0.003)\end{array}$ & $\begin{array}{l}0.007 * * * \\
(0.0024)\end{array}$ & $\begin{array}{l}0.0048 * * * \\
(0.0018)\end{array}$ & $\begin{array}{c}0.0933 * * * \\
(0.0277)\end{array}$ & $\begin{array}{l}0.0568 * * \\
(0.0233)\end{array}$ & $\begin{array}{l}0.0378 * * \\
(0.0181)\end{array}$ \\
\hline 2-Year College & $\begin{array}{c}0.0005 \\
0(.0035)\end{array}$ & $\begin{array}{l}-0.0018 \\
(0.0029)\end{array}$ & $\begin{array}{l}-0.0039 \\
(0.0025)\end{array}$ & $\begin{array}{l}-0.0012 \\
(0.0019)\end{array}$ & $\begin{array}{c}0.0397 \\
(0.0314)\end{array}$ & $\begin{array}{c}0.0211 \\
(0.0286)\end{array}$ & $\begin{array}{l}0.0067 \\
(0.02)\end{array}$ \\
\hline Observations & 341834 & 341834 & 341834 & 341834 & 341834 & 341834 & 341687 \\
\hline R-squared & 0.0547 & 0.0473 & 0.0385 & 0.0337 & 0.127 & 0.316 & 0.3798 \\
\hline Mean DV & 0.204 & 0.156 & 0.113 & 0.086 & 11.252 & 5.145 & 5.404 \\
\hline $\begin{array}{l}\text { Elasticity of } 4 \text {-Year } \\
\text { College }\end{array}$ & 0.2284 & 0.2492 & 0.2673 & 0.2409 & 0.03568 & 0.04745 & 0.03008 \\
\hline $\begin{array}{l}\text { Elasticity of 2-Year } \\
\text { College }\end{array}$ & 0.00405 & -0.01906 & -0.05687 & -0.02376 & 0.00583 & 0.00677 & 0.00206 \\
\hline PUMA FE & Yes & Yes & Yes & Yes & Yes & Yes & Yes \\
\hline Birth Cohort FE & Yes & Yes & Yes & Yes & Yes & Yes & Yes \\
\hline Individual Controls & Yes & Yes & Yes & Yes & Yes & Yes & Yes \\
\hline $\begin{array}{l}\text { PUMA by Birth Cohort } \\
\text { Linear Trend }\end{array}$ & Yes & Yes & Yes & Yes & Yes & Yes & Yes \\
\hline
\end{tabular}

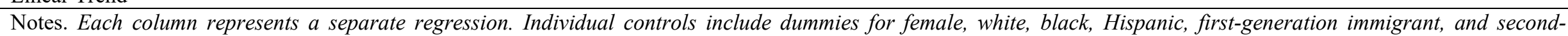
generation immigrant. Standard errors, clustered at the county-PUMA level, are in parentheses.

$* * * \mathrm{p}<.01, * * \mathrm{p}<.05, * \mathrm{p}<.1$ 
Table 7 - Heterogeneity of the Main Results by Gender, Race, and Ethnicity

\begin{tabular}{|c|c|c|c|c|}
\hline & \multicolumn{4}{|c|}{ Outcome: Death Age (Months) } \\
\hline & (1) & (2) & (3) & (4) \\
\hline Male×4-Year & $0.027 * * *$ & & & \\
\hline College & $(0.01)$ & & & \\
\hline Male×2-Year & $0.0619 * *$ & & & \\
\hline College & $(0.0257)$ & & & \\
\hline Male & $\begin{array}{c}-7.2191 * * * \\
(0.0926)\end{array}$ & & & \\
\hline Other $\times 4-$ Year & & 0.0826 & & \\
\hline College & & $(0.0653)$ & & \\
\hline Other $\times 2$-Year & & 0.035 & & \\
\hline College & & $(0.1134)$ & & \\
\hline Other & & $\begin{array}{c}-3.5842^{* * *} \\
(0.627)\end{array}$ & & \\
\hline Black $\times 4-Y e a r$ & & & -0.0117 & \\
\hline College & & & $(0.0141)$ & \\
\hline Black $\times 2-$ Year & & & $0.1178^{* * *}$ & \\
\hline College & & & $(0.0349)$ & \\
\hline Black & & & $\begin{array}{c}-4.017 * * * \\
(0.1455)\end{array}$ & \\
\hline $\begin{array}{l}\text { Hispanic } \times 4- \\
\text { Year College }\end{array}$ & & & & $\begin{array}{c}0.0238 \\
(0.0213)\end{array}$ \\
\hline Hispanic $\times 2-$ & & & & $-0.0744 * *$ \\
\hline Year College & & & & $(0.0315)$ \\
\hline Hispanic & & & & $\begin{array}{c}0.5247 \\
(0.3231)\end{array}$ \\
\hline 4_Year Colleoe & $0.1173^{*}$ & $0.1311 *$ & $0.1325^{* *}$ & $0.1312^{*}$ \\
\hline 4-y ear college & $(0.0696)$ & $(0.0672)$ & $(0.0668)$ & $(0.0671)$ \\
\hline & 0.0126 & 0.0467 & 0.0407 & 0.0498 \\
\hline 2-Y ear College & $(0.0523)$ & $(0.0538)$ & $(0.0538)$ & $(0.0537)$ \\
\hline Observations & 3849792 & 3849792 & 3849792 & 3849792 \\
\hline R-squared & 0.4474 & 0.4474 & 0.4474 & 0.4474 \\
\hline Mean DV & 831.4 & 831.4 & 831.4 & 831.4 \\
\hline Birth Cohort FE & Yes & Yes & Yes & Yes \\
\hline County FE & Yes & Yes & Yes & Yes \\
\hline $\begin{array}{l}\text { Individual } \\
\text { Controls }\end{array}$ & Yes & Yes & Yes & Yes \\
\hline $\begin{array}{l}\text { Notes. Each colu } \\
\text { Hispanic, first-g } \\
\text { level, are in pare } \\
* * * \mathrm{p}<.01, *^{*} \mathrm{p}<\end{array}$ & $\begin{array}{l}\text { nts a separ } \\
\text { nmigrant, }\end{array}$ & $\begin{array}{l}\text { n. Individua } \\
\text { eneration it }\end{array}$ & $\begin{array}{l}\text { clude dumm } \\
\text { andard err }\end{array}$ & $\begin{array}{l}\text { white, } b l \\
\text { at the co }\end{array}$ \\
\hline
\end{tabular}


Table 8 - Heterogeneity of the Main Results by Subsamples

\begin{tabular}{|c|c|c|c|c|c|c|c|c|c|c|}
\hline & \multicolumn{10}{|c|}{ Outcome: Death Age (Months)/Subsample: } \\
\hline & $\begin{array}{l}\text { Region: } \\
\text { Northeast }\end{array}$ & $\begin{array}{l}\text { Region: } \\
\text { Midwest }\end{array}$ & $\begin{array}{l}\text { Region: } \\
\text { South }\end{array}$ & $\begin{array}{l}\text { Region: } \\
\text { West }\end{array}$ & $\begin{array}{c}\text { Birth } \\
\text { Year }<1932\end{array}$ & $\begin{array}{c}\text { Birth } \\
\text { Year } \geq 1932\end{array}$ & $\begin{array}{c}\text { Below } \\
\text { Median } \\
\text { Father } \\
\text { Education }\end{array}$ & $\begin{array}{c}\text { Above } \\
\text { Median } \\
\text { Father } \\
\text { Education }\end{array}$ & $\begin{array}{c}\text { Below Median } \\
\text { County } \\
\text { Population }\end{array}$ & $\begin{array}{c}\text { Above } \\
\text { Median } \\
\text { County } \\
\text { Population }\end{array}$ \\
\hline & $(1)$ & $(2)$ & (3) & (4) & $(5)$ & $(6)$ & $(7)$ & $(8)$ & $(9)$ & $(10)$ \\
\hline $\begin{array}{l}\text { 4-Year } \\
\text { College }\end{array}$ & $\begin{array}{c}-0.008 \\
(0.1076)\end{array}$ & $\begin{array}{c}0.2773 * * \\
(0.1118)\end{array}$ & $\begin{array}{c}0.0488 \\
(0.2321)\end{array}$ & $\begin{array}{c}0.0592 \\
(0.1403)\end{array}$ & $\begin{array}{c}0.0434 \\
(0.0864)\end{array}$ & $\begin{array}{c}0.2851 \\
(0.2123)\end{array}$ & $\begin{array}{c}0.101 \\
(0.0917)\end{array}$ & $\begin{array}{c}0.2117^{* *} \\
(0.0948)\end{array}$ & $\begin{array}{c}0.318 \\
(0.2232)\end{array}$ & $\begin{array}{l}0.1174 * \\
(0.0692)\end{array}$ \\
\hline $\begin{array}{l}\text { 2-Year } \\
\text { College }\end{array}$ & $\begin{array}{c}0.125 \\
(0.1034)\end{array}$ & $\begin{array}{c}0.1644 \\
(0.1459)\end{array}$ & $\begin{array}{c}0.3461 \\
(0.2633)\end{array}$ & $\begin{array}{l}-0.1622 \\
(0.1206)\end{array}$ & $\begin{array}{c}0.0566 \\
(0.0926)\end{array}$ & $\begin{array}{c}0.3117^{*} \\
(0.182)\end{array}$ & $\begin{array}{c}0.026 \\
(0.0858)\end{array}$ & $\begin{array}{c}0.0209 \\
(0.0747)\end{array}$ & $\begin{array}{l}-0.2741 \\
(0.2327)\end{array}$ & $\begin{array}{c}0.0706 \\
(0.0638)\end{array}$ \\
\hline Observations & 952090 & 1223248 & 1297867 & 376587 & 2634682 & 1215110 & 2279673 & 1024386 & 1927602 & 1922190 \\
\hline R-squared & 0.43 & 0.4484 & 0.4524 & 0.4609 & 0.1709 & 0.216 & 0.4379 & 0.4859 & 0.4532 & 0.4407 \\
\hline Mean DV & 834.5 & 832.9 & 827.0 & 833.6 & 860.2 & 768.7 & 832.0 & 823.7 & 829.3 & 833.4 \\
\hline $\begin{array}{l}\text { Birth Cohort } \\
\text { FE }\end{array}$ & Yes & Yes & Yes & Yes & Yes & Yes & Yes & Yes & Yes & Yes \\
\hline County FE & Yes & Yes & Yes & Yes & Yes & Yes & Yes & Yes & Yes & Yes \\
\hline $\begin{array}{l}\text { Individual } \\
\text { Controls }\end{array}$ & Yes & Yes & Yes & Yes & Yes & Yes & Yes & Yes & Yes & Yes \\
\hline
\end{tabular}

Notes. Each column represents a separate regression. Individual controls include dummies for female, white, black, Hispanic, first-generation immigrant, and second-generation immigrant. Standard errors, clustered at the county level, are in parentheses.

$* * * \mathrm{p}<.01, * * \mathrm{p}<.05, * \mathrm{p}<.1$ 


\section{Figures}
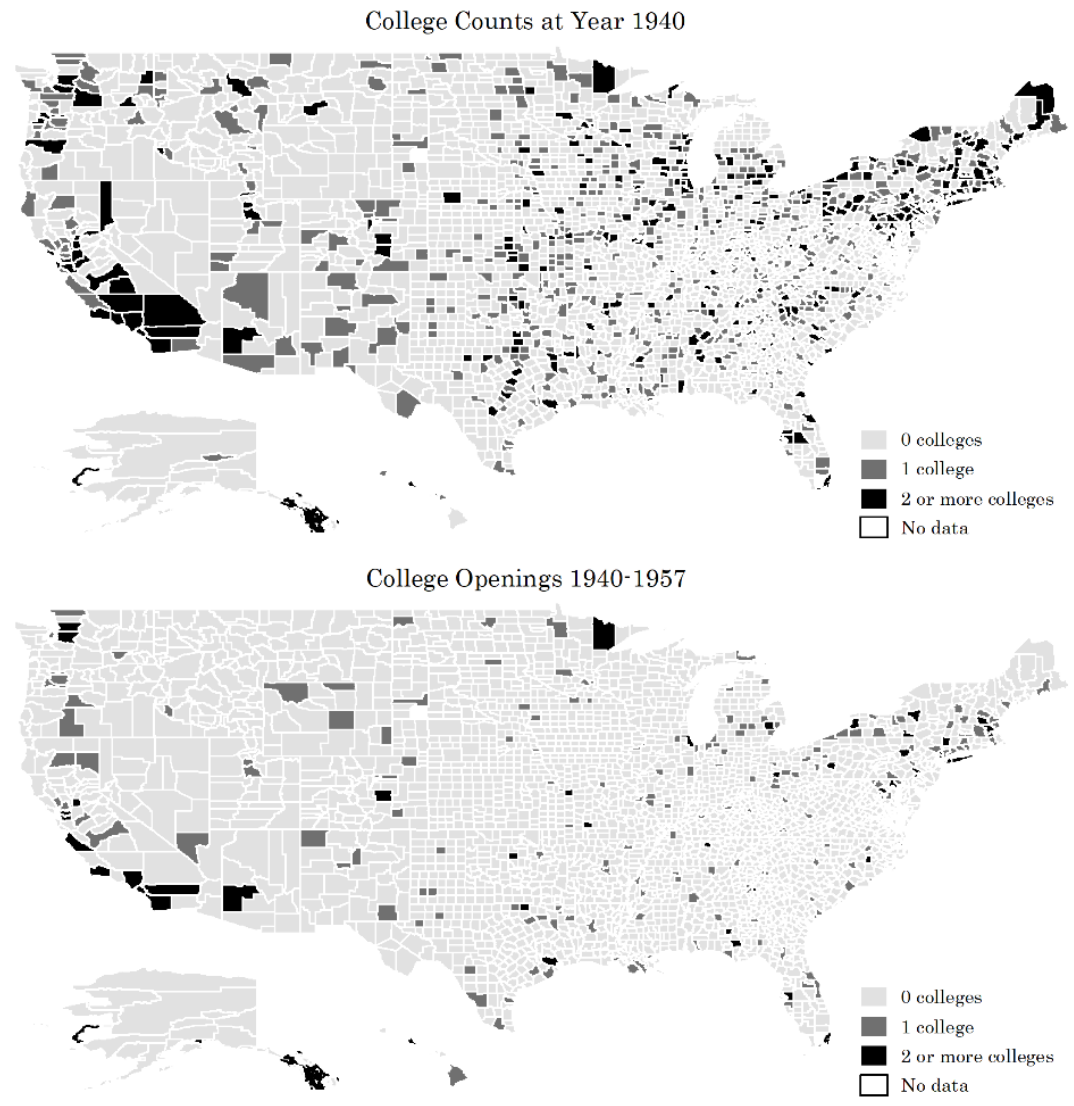

Figure 1 - Geographic Distribution of College Inventory at 1940 and College Expansion over the Years 19401957 


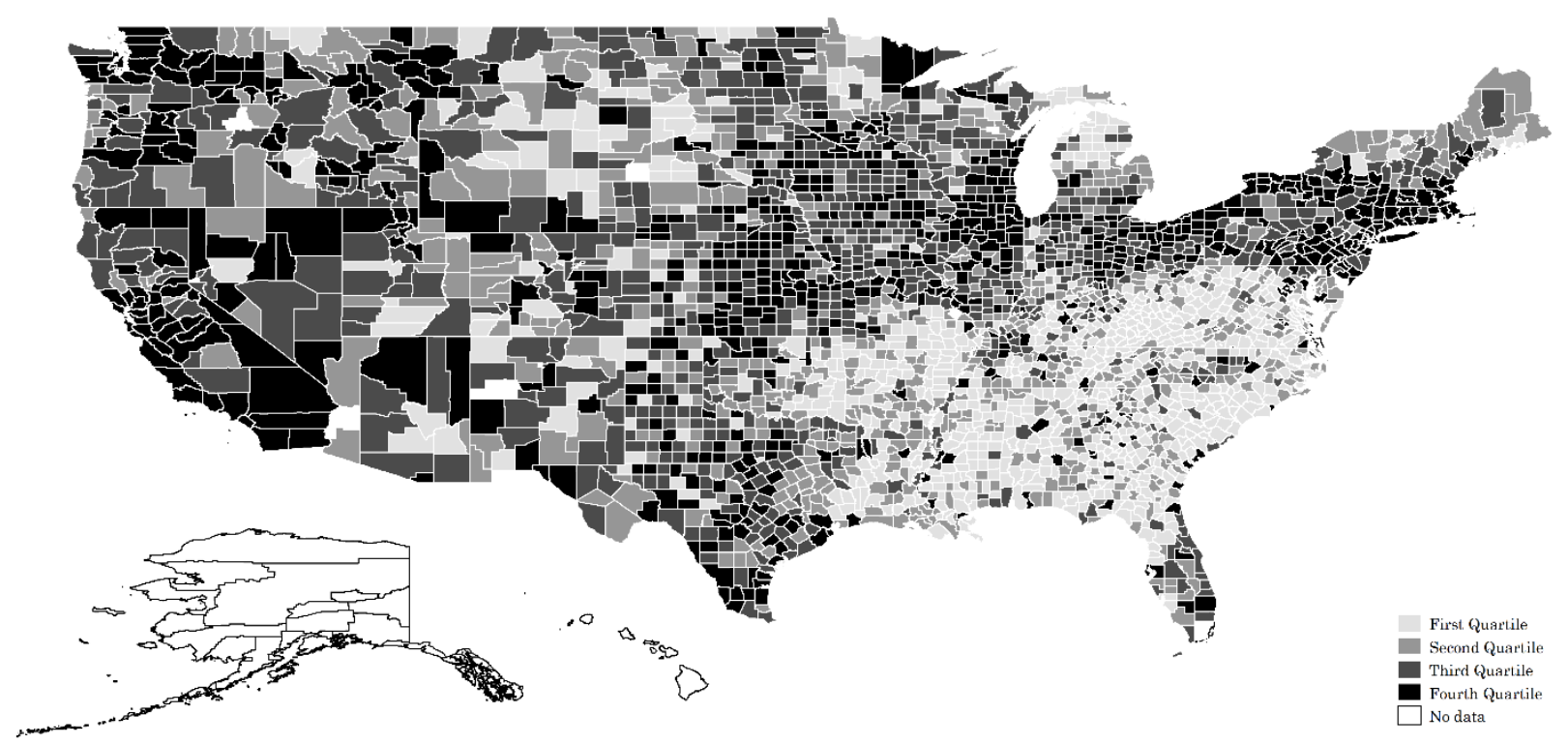

Figure 2 - Geographic Distribution of Age-at-death by Place of Residence during Childhood and Adolescence at 1940 for Cohorts Born between 1923-1940 and Died between 1988-2005 


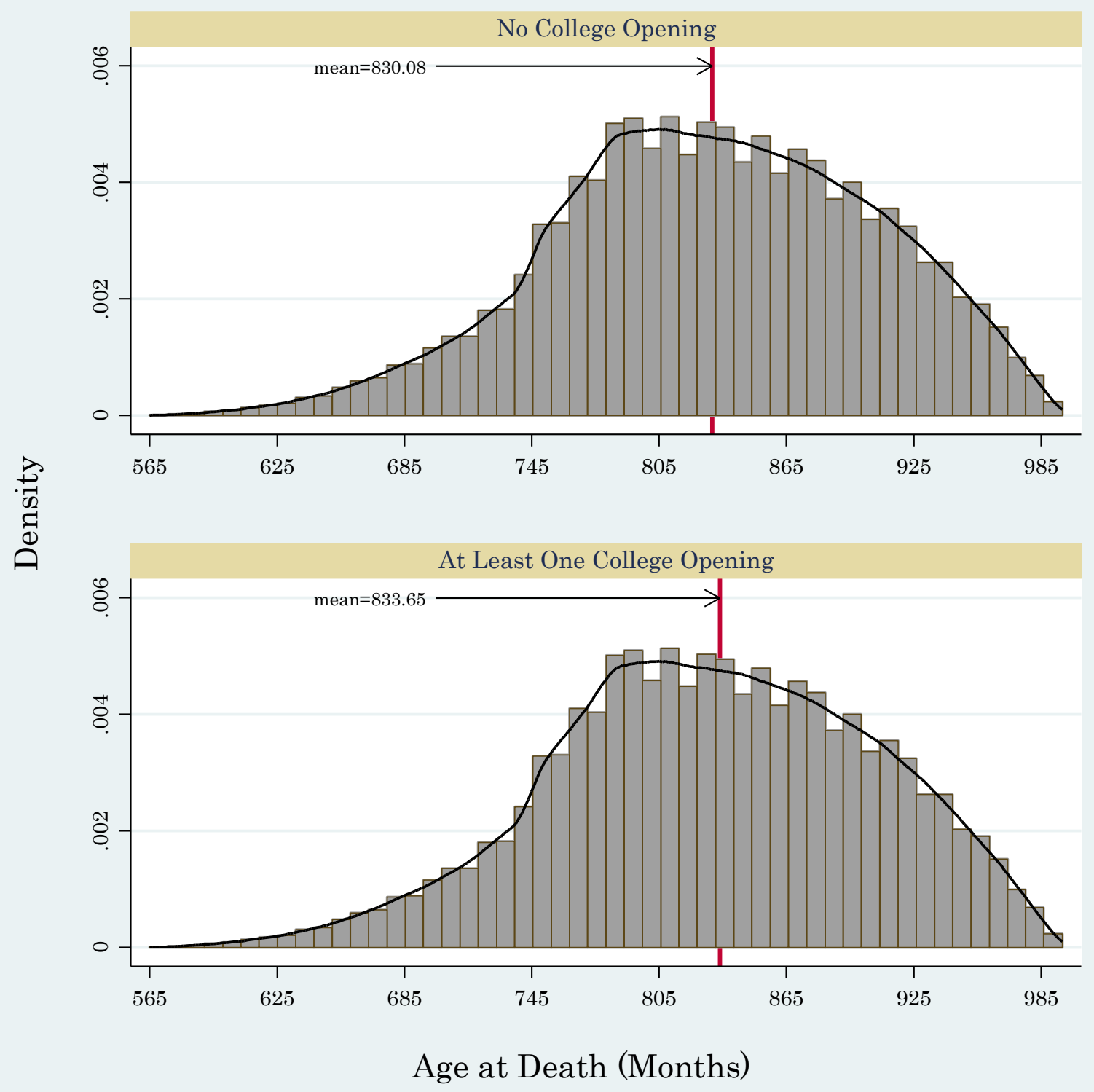

Figure 3 - Density Distribution of Age-at-death for Counties without/with College Expansion 

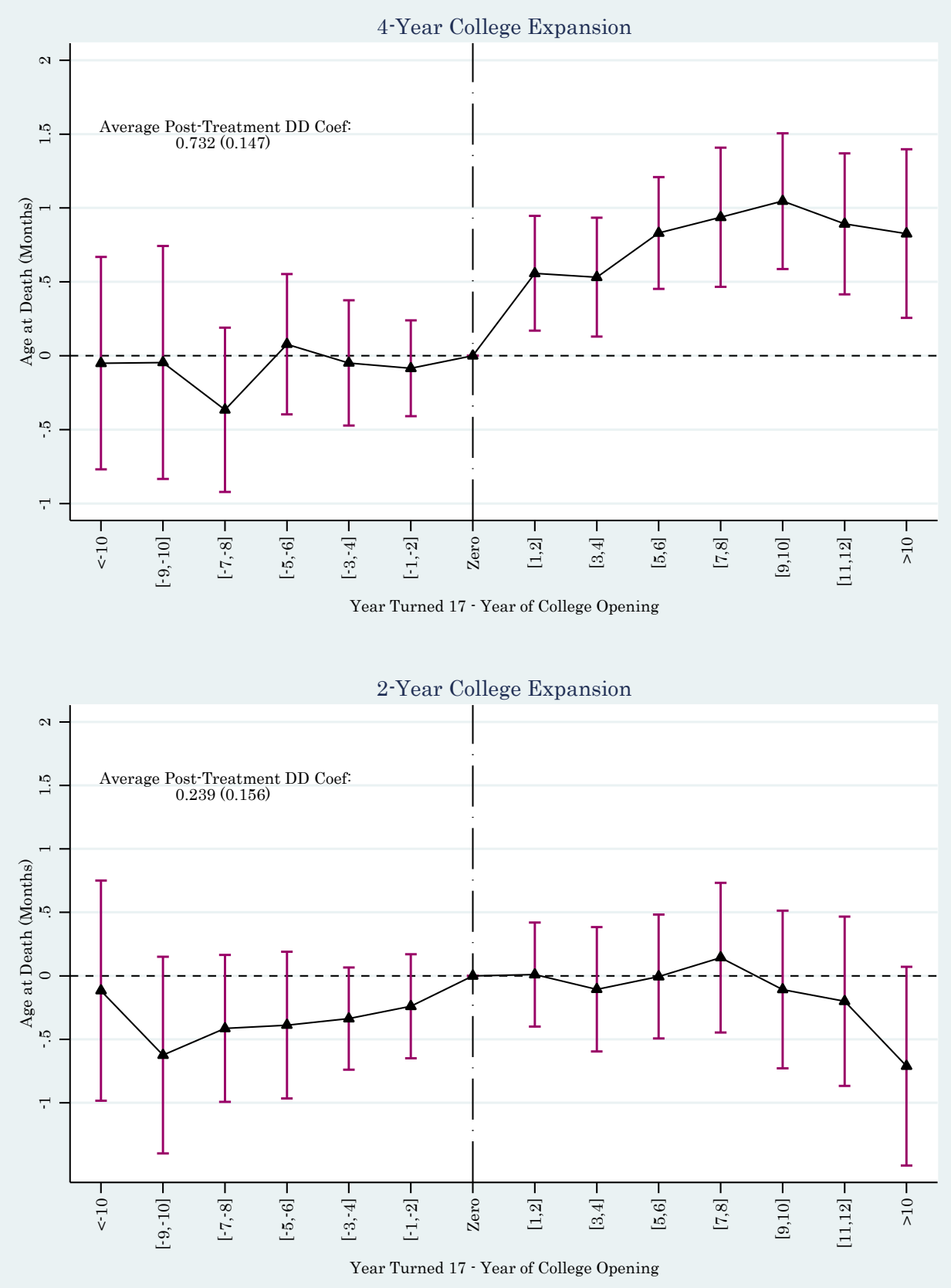

Figure 4 - Event-Study Results of College Expansion on Age-at-death 


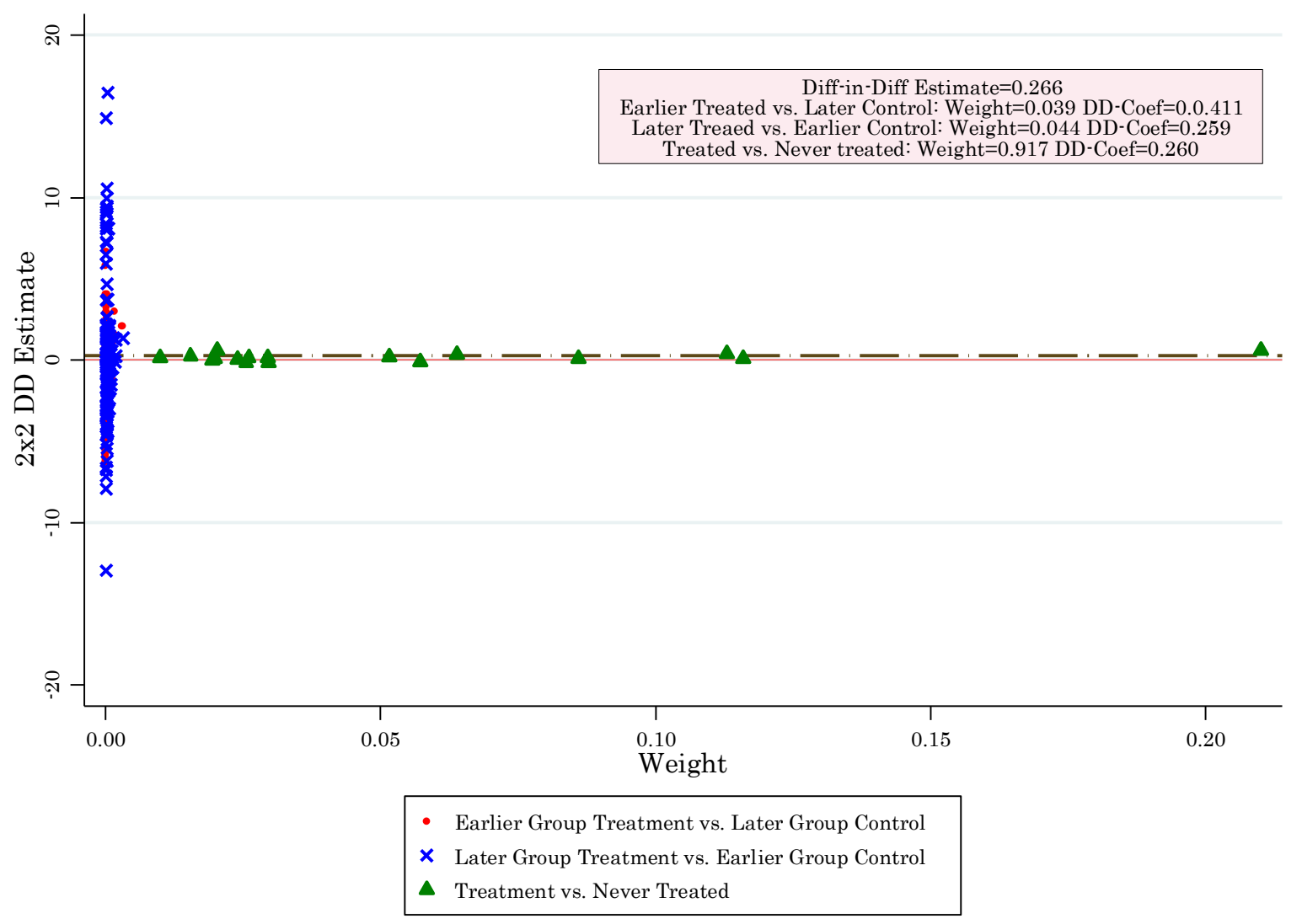

Figure 5 - Bacon Decomposition of Difference-in-Difference Estimate 